DOI https://doi.org/10.36059/978-966-397-242-8-7

Романова Н. В.,

доктор філологічних наук, доцент, професор кафедри німецької та романської філології

Херсонського державного університету,

м. Херсон

\title{
ЛІНГВІСТИКА ЕМОЦІЙНОГО ДОСВІДУ ГЕРМАНСЬКОГО ФЕОДАЛЬНОГО ТОВАРИСТВА ХІІІ СТОЛІТТЯ
}

Анотація. Дослідження розкриває особливості семантики емоційного досвіду германського феодального товариства XIII cm. Акцентовано на тому, що емоційний досвід германського феодального товариства XIII cm. $\epsilon$ сукупністю знань німецького етносу про пережиті емоції германцями (ірландцями, норвежиями, датчанами) та іншими народами (індусами, португальцями). Встановлено структуру населення, систематизовано емоції, окреслено морально-етичні проблеми дружби й кохання, визначено поняття маніакальної любові, виявлено три вербальні рівні реалізації емоцій, що корелюють з мовною картиною світу шпільмана. Аналіз мовних емотивних одиниць здійснено за схемою: від словника до тексту. Доведено, що емоційний досвід лінгвоспільноти формувався під впливом язичницького й християнського вірування, германських і не германських культур, змінювався з віковим цензом людини.

\section{Вступ}

Поняття «емоційний досвід» не має загальноприйнятого визначення. Джерело «емоційності» вбачають у зовнішніх обставинах і внутрішньому стані людського організму [17, с. 213-214]. Зовнішні обставини впливають на людину загалом і її емоційну сферу зокрема, викликають у ній певні емоції, внутрішній стан пов'язаний 3 душевними змінами, що формуються після пережитих людиною ситуацій. Межа між зовнішніми обставинами і внутрішнім станом невидима, розмита, формальна, діалектична: без зовнішніх обставин немає внутрішнього стану, без внутрішнього стану немає зовнішніх обставин. 
Емоційний досвід германського феодального товариства XIII століття інтерпретуємо як сукупність знань німецького етносу про пережиті емоції германцями (ірландцями, норвежцями, датчанами) та іншими народами (індусами, португальцями). Емоції визначаємо як реакцію на конкретні зовнішні обставини [15, с. 390]. або на конкретний внутрішній стан. У рамках цього робочого терміна будемо виокремлювати емоції середньовічної людини.

Середньовічна людина була віруючою. Її віра амбівалентна язичницько-християнська. Свої вчинки, почуття й емоції звіряли зі Святим Письмом.

Дозволимо собі нагадати, що однією з перших емоцій БогаТворця є схвалення. Бог оцінює й хвалить результат кожного дня Свого Творіння, підкреслює правильність Своїх Дій, акцентує увагу на Своїй Позитивній Поведінці.

Творець використовує похвалу впродовж шести днів з позиції Абсолютної оцінки [27, с. 26]. Структура останньої вельми складна й багатогранна. Вона включає в себе, по-перше, природу трьох стихій темряву, землю, воду, по-друге, природу Творця - «Дух Божий», потретє, комунікативну діяльність - «I сказав Бог», по-четверте, творчий процес - «I Бог твердь учинив», по-п'яте, номінативну діяльність - «І назвав Бог твердь: «Небо»», по-шосте, концептуальну програму - ««Нехай станеться твердь посеред води, $і$ нехай відділяє вона між водою й водою»», по-сьоме, часове членування діяльності «І був вечір, і був ранок, - день перший», по-восьме, духовну діяльність «I благословив їх Бог», по-дев'яте, сенсорну діяльність - «I побачив Бог усе, що вчинив», по-десяте, ритуальну діяльність - «I поблагословив Бог день сьомий, і його освятив» [3, с. 9-10].

Таким чином, виникає позитивний доброчесний цикл, у якому сакральні заслуги безперервно оцінюються й примножуються.

Визнаючи вклад Бога в процес створення планети Землі, iㅣ рослинного й тваринного світу, а також людини, віруючий/-а віднаходить у Творці Ідеал, гідний наслідування. Наслідують як Бога-Творця, так і Його єдинородного безгрішного Сина - Iсуса Христа. При цьому Отця й Сина прославляють і звеличують. Людина шукає для себе «ідеальне місце проживання»- Царство Небесне. Звідси й знецінення земного життя.

Цікаво, що перші люди, створенні Богом, зламавши Його заборону, переживають емоцію задоволення. Однак їі активація відбувається тільки в жіночому організмі на основі когнітивних 
процесів «I побачила жінка, що дерево добре на їжу, і принадне для очей, і пожадане дерево, щоб набути знання» [3, с. 11].

Чоловічий організм, на відміну від жіночого, не реагує на зовнішній подразник, не розпізнає й не виокремлює себе як окреме ціле 3 навколишнього середовища $[11$, с. 96]. Він залишається незмінним до тих пір, доки ситуація й обставини кардинально не змінюються.

Механізмом трансформації є знання «[...] і пізнали, що на́гі вони. I зшили вони фігові листя, і зробили опаски собі» [3, с. 11].

Очевидно молодший або жіночий організм не оцінює ступінь небезпеки, ігнорує загрозу, не надає їй значення, тому не боїться наслідків. Старший або чоловічий організм переборює небезпеку спочатку тілесно, удаючись до втечі «[...] I сховався Адам і його жінка від Господа Бога серед дерев раю», потім словесно, описуючи свій емоційний стан «А той відповів: «Почув я Твій голос у раю і злякався, бо нагий я, - і сховався»» [там само].

Тут репрезентовано дві емоції чоловіка - страх і сором і одну емоцію жінки - сором. За якістю переживання ці емоції ще не розрізняються. Їх уявляють як обов'язок, норму в собі.

На нашу думку, невербальне, вербальне або комплексне невербально-вербальне вираження емоцій залежить насамперед від віку, статі, ситуації, знань людини про навколишній світ.

Германське феодальне товариство XIII ст. створює новий ідеал воїна-героя. Виникає «вільне суперництво» або «конкуренція» ідеалів: сакральний - світський. Межею конкуренції є Сакральний Ідеал.

\section{1. Історія лінгвістики емоцій. Емоції як міждисциплінарний феномен}

\section{1. Етапи розвитку історії лінгвістики емоцій}

Під етапом розвитку історії лінгвістики емоцій розуміємо мовний поділ наукової спадщини на певні хронологічні періоди. Ці періоди відрізняються один від одного предметом вивчення, методологічною й лінгвістичною парадигмою.

Виокремлюють п'ять етапів розвитку історії лінгвістики емоцій:

1) нехтування (давні греки);

2) визнання вигуків самостійною частиною мови та їх вивчення (римляни);

3) гостра критика логічних підходів до вигуків і формування психологічного напряму (друга половина XIX ст.); 
4) диференціація вигуків, функціонування їх у мовленні, конотація як доповнення предметно-логічного значення слова (друга половина ХХ ст.);

5) розробка проблем мовної номінації, поєднання лінгвістики 3 психологією, мовна семантика різних рівнів і тексту, співвідношення емотивного й раціонально-логічного в семантичній структурі мовних знаків, виділення емотивно маркованих лексем (емоційні вигуки, частки) (початок XXI ст.) [8, с. 10-12].

Як бачимо, на першому етапі ставлення дослідників до лінгвістики емоцій негативне або неактуальне, тобто емоції лишаються на периферії, на другому етапі лінгвістика емоцій дістає вже позитивне забарвлення принаймні на рівні частин мови. Між другим і третім етапами помітно не лише суттєвий часовий розрив - понад 2 тис. років, але й прагнення інтеграції наукових знань про емоції в рамках лінгвістики й психології [12, с. 1064-1065]. Отже, третій етап тлумачимо як «новаторський», оскільки лінгвістику емоцій мислять як продукт соціально-психологічноісторичного розвитку людства й суспільства.

На четвертому етапі відбувається уточнення й розмежування логічного, наукового й лінгвістичного понять «емоція», на п'ятому або «прагматичному» етапі лінгвістику емоцій систематизують, комбінують, порівнюють, зіставляють і, зрештою, моделюють у річищі теорії і практики [2, с. 76-122].

Останнім часом (XXI ст.) лінгвістику емоцій досліджують комплексно як категорію високого рівня абстрагування, що належить суспільній, фізичній, психічній і культурній природі людини [20; 21]. При цьому використовують когнітивний підхід, що грунтується «на взаємодії мови й мислення» [23, с. 18]. В мові, як відомо, відображено національні особливості й специфіка картини світу, онтологічними характеристиками якої $є$ : «1) наявність імен концептів; 2) нерівномірна концептуалізація різних фрагментів дійсності в залежності від їх важливості для життя відповідного етносу; 3) специфічна комбінаторика асоціативних ознак цих концептів; 4) специфічна кваліфікація певних предметних галузей; 5) специфічна орієнтація цих галузей на ту чи ту сферу спілкування» [13, с. 129-130]. Мислення формується і розвивається в процесі пізнавальної діяльності людини, охоплює досвід попередніх генерацій [17, с. 169]. 


\section{2. Емоції у науковому форматі}

Зауважимо, що між психологічним визначенням емоції $\mathrm{i}$ лінгвістичними даними про них існує певна розбіжність, яку пояснюють специфікою «мовних функцій»: людина не лише виражає свої емоції вербально й/чи невербально, але й може збудити, викликати їх в адресата в процесі комунікації [32, с. 7]. Інакше кажучи, людські емоції $\epsilon$ суб'єктивним і водночас об'єктивним відображенням у мові, а також інструментом відображення навколишнього світу.

Важливо враховувати й культуру етносу, й час його фізичного існування, й місце проживання.

Культура дає людині певне почуття міри [39], коли вона зіштовхується із безладом як наслідком життєвої ситуації, допомагає поєднати людей емоційно, обмежуючи одні види емоцій «невідповідні», «небажані» або підсилює інші - «відповідні», «бажані» [42]. Вона формує особистість і регулює її поведінку, слугує підгрунтям моральних принципів, $\epsilon$ показником цивілізації.

Фізичний час змінює погляд людини на життя і його якість, орієнтує іï на нові досягнення [29, с. 72]. Він пливе рівномірно, в один бік - з минулого в майбутнє. Його швидкість залежить від матерії, якій він належить.

Наприклад, планета Земля має один час, загальний для всіх їі мешканців і об'єктів, у рослин, тварин, мінералів, людей другий або «особистий» (біологічний) час, який підпорядковується загальному планетарному земному часу й узгоджується з ним. У молодому й здоровому організмі час збігає повільно, оскільки такий організм містить більше життєвої енергії, ніж старий і хворий. Крім того, організм тратить життєву енергію на якусь виконувану роботу. Якщо робота захоплює й подобається, то людині здається, що час летить i, навпаки, якщо робота не захоплює й не подобається, то час для людини немов розтягується. Тут не можна ігнорувати й роль психіки, почуттів і емоцій, які прискорюють час цікавої роботи та уповільнюють, гальмують нецікаву, відповідно.

Стресові ситуації, «надлишкові» емоції різко скорочують життя земного організму, спокій або відсутність емоцій сприяють продовженню життя.

Місце проживання формує центр, межу, маршрут у просторі $[9$, с. 9]. Центр притягує й акумулює у собі «всі сили Всесвіту, темні й світлі, добрі й злі» $[18$, с. 104], вони оберігають людину до самої 
межі, де починається ««чужий» простір, його закони й сили, що впливають» $[19$, с. 64].

Рухаючись через «свій» або «чужий» простір, людина прокладає маршрути, вносить певний порядок у довкілля [30, с. 253].

Зрозуміло, що дослідження лінгвістики емоцій повинно бути комплексним, з урахуванням напрацювань у суміжних лінгвістиці галузях, як-от: антропологія, етнографія, історія суспільства, культурологія, соціологія, психологія, психолінгвістика, когнітивна лінгвістика тощо.

\section{2. Психологічний портрет германської еліти}

\section{1. Воїн-герой. Можновладці}

Уявлення середньовічної людина про навколишній світ невід'ємне від категорій «справедливості, віри, честі, вірності» [9, с. 10], «подвигу» $[25$, c. 6]. Це означає, що авторитетом у германському феодальному товаристві XIII ст. користувався воїн-герой. Він був ідеалом, еталоном, зразком, що вірно служив королю і його родині.

Воїн-герой брав активну участь у війнах, битвах, турнірах, поєдинках.

Походження та виховання воїна-героя, як правило, шляхетне, інтелект відносно високий, матеріальний статус варіативний: від багатого до бідного.

До прикладу, в Ірландії воїн-герой асоціювався з королем і його старшими родичами. Король очолював королівство, раціонально (без емоцій) ним керував, судив і карав винуватців, проводив певну внутрішню й зовнішню політику, вів переговори, оголошував війну, ходив у походи, на смерть стояв у бою, захищав бідних і знедолених, власну сім'ю, своє королівство, виконував подружній обов'язок, підтримував кревні зв'язки та дружні стосунки.

Принципово важливим для короля будо дотримування традицій, звичаїв, обрядів. Він активний учасник усіх турнірів і свят королівства, любить музику й пісні шпільманів, цікавиться естетичними «новинками», хоч останні можуть кардинально змінити долю його сім'ї й країни загалом.

Готовий ризикувати собою та іншими.

Дошкульним місцем короля вважаємо контроль емоцій.

Наприклад, втративши малолітнього сина, ірландський король Зігебант (букв. «переможна стрічка») плаче, ридає, поринає в 
глибоку скорботу, зберігаючи при цьому позитивне ставлення не лише до навколишнього світу, а й до скоєного лютим, жорстоким грифом зла, а також до докорів королеви Ути. Його горю співчуває тільки чоловіча частина двору, жінки ж оцінюють крадіжку дитини як духовну норму, закріплену християнством [33, с. 14-16]. Тут простежуємо протистояння інтенсивності емоції горя ціннісним орієнтирам, що наповнюють психологічний феномен новим смисловим змістом. В результаті емоція горя поступово сполучується з фізичною смертю людини.

Семантичний розвиток емоції горя можна зобразити схематично двома моделями:

1) плач $\rightarrow$ голосіння $\rightarrow$ скорбота (батько/король);

2) байдужість $\rightarrow$ безтурботність $\rightarrow$ докір (матір/королева).

Кільця цих ланцюжків репрезентують архаїчний тип художньої свідомості [34, с. 71-72], еквівалентні «мові тіла» (батько/король) та основним функціям мови (матір/королева). «Мову тіла»можна звести до інтенсивності голосу й негативного емоційного стану, імпліцитно до міміки й пози. Основні функції мови - комунікативна й емотивна - співвідносимо зі спілкуванням королеви з королем, у якому реалізовано їх почуття й емоції.

Механізмом виходу з емоції горя є воля Бога

"læg' líut tót,

ez müese sich verenden, als got von himele gebôt." [33, с. 15].

Емоційна поведінка королеви синхронізована 3 етикетом i християнською релігією. Етикет передбачає наявність розуму, чесноти, доброти та вроди, християнська релігія вимагає, в свою чергу, упокорення й слухняності.

Судячи 3 усього, етикет i християнська релігія були для шляхетної пані своєрідним регулятором соціальної та культурної норми, допомагали зміцнювати соціальний порядок та гармонію.

Важливою складовою механізму формування емоцій королеви $\epsilon$ iii функції. 3 одного боку, королева поєднує в собі політика й заступницю, а 3 другого - репрезентує господарника й мистецтвознавця. Функції політика й господарника охоплюють не стільки самостійність королеви, скільки контролювання й корегування дій короля. В цьому контексті королева виступає гарантом політичного й/або економічного успіху в королівстві. 
Заступництво королеви тому чи тому підданому тісно пов'язане зі щедрістю, милістю, ласкою, усмішкою. Очевидно, що королева обізнана з математикою та психологією на практиці.

Звернімо увагу на королеву як мистецтвознавця. Перед нами ерудована людина, поліглот, знавець музики, співу й живопису. Королева стежить за модними тенденціями в чоловічому й жіночому одязі, дотримується їх, добирає й замовляє витончені й розкішні ювелірні жіночі вироби, розробляє дизайн військових суден, холодної зброї тощо.

У королеви $є$ й інші функції зокрема дружини, матері, подруги, коханої, «дами серця», парафіянки. Епітети до наведених функцій «любляча й вірна», «турботлива», «справжня», «потенційна», «порядна», «богобоязлива» мають позитивну семантику та ілюструють імпліцитно поведінку королеви.

Кожна 3 аналізованих функцій неподільна. Їх потрібно розглядати в симбіозі. Ця проблема може бути й повинна стати перспективою дослідження.

Королівські родини класифікуємо на два основні типи: репродуктивні й нерепродуктивні. Репродуктивні королівські родини мають дітей (1-2), нерепродуктивні не мають, вони бездітні. Причину бездітності пояснюємо через міфопоетичний, біологічний і фізіологічний чинники.

Міфопоетичний чинник передбачає викрадення малолітніх дітей злими хижаками - грифами-велетнями, що мешкають у невідомій місцевості. «Злочинці» з'являються завжди неочікувано. Їх природа десакралізована - належать до темних неземних сил.

Біологічний чинник апелює до природної або неприродної (насильницької) смерті дітей.

Фізіологічний чинник залежить від процесу статевого дозрівання шлюбної пари: дівчина 12-14 років, юнак 14-18, відповідно. Активаторами статевого дозрівання вважають: генетику, вагу, стрес, дисбаланс між жіночими й чоловічими гормонами, харчування, хвороби [24].

Кількість дітей в репродуктивних королівських родинах дає змогу класифікувати нащадків на парних і непарних, гомо- й гетеростатевих, старших і молодших.

Парні діти асоціюються з числом «два», непарні - з числом «один».

Репрезентантами гомостатевих дітей $є$ хлопчики або дівчатка, гетерогенних - хлопчики й дівчатка. 
Впадає у вічі «старшинство» хлопчиків та «меншинство» дівчаток. При цьому старший брат завжди прислухається до молодшої сестри та питає у неї поради. Маємо релікти матріархату.

Неможна не згадати й той факт, що психологічний стан еліти впливає на їі соціалізацію та загальну культуру поведінки.

Наприклад, юні принцеси соромляться розповідати графові сальмейському про свої страждання на дикому острові. Вони ніяковіють перед незнайомцем, дорослим озброєним чоловіком у супроводі воїнів-моряків. У цьому випадку йдеться про своєрідне почуття ураження «Я», утягнутого в взаємодію з «новим», «чужим», небезпечним для них навколишнім світом. Це почуття примушує дівчат обмежувати себе вербально від контакту, котрий тривожить їх. Дівчата бояться і водночас соромляться одягати одяг паломників на борту, хоч від їхніх суконь, сплетених самостійно з трави, залишилися тільки фрагменти. Принцеси стуляються, притягають коліна до грудей, стараються стати як можна менш помітними [33, с. 26-29].

Перед нами приклади переживання емоцій збентеження, засоромлення, сором'язливості й боязні, збудовані на спогадах, життєвому досвіді й чуттєвості дівчат до «невідомого», «чужого», «чоловічого». Ці емоції оголюють норму соціальної поведінки жінки-іноземки в екстремальній ситуації.

Емоційна поведінка королівської рідні залежить від безпеки проживання та наказів короля: Якщо рідні погрожують злі сусіди або недруги, васали воюють з ними до перемоги, демонструючи свою силу, хоробрість, свій темперамент. Коли королю/королеві потрібна якась допомога чи моральна підтримка, рідня вважає за честь виконати будь-який наказ свого володаря чи його дружини.

Пригадаймо сватання датського короля Гетеля [там само, с. 45-56].

Гетель був сиротою, що, зрозуміло, затьмарювало його життя. Друзі порадили юному королю закохатися. Тобто кохання інтерпретують як соціальное «Я» людини, невід'ємну частину їі природи, гарантію щасливого майбутнього.

Наречена повинна бути не просто знатною, вродливою й милою, а суперзнатною й супервродливою. Цим високим вимогам відповідала тільки Гільда - дочка гордого ірландського короля. Зразком і еталоном вроди була матір. Щоправда, опис її зовнішності відсутній.

Добути красуню міг лише старий відважний Вате, що виховав Гетеля. Девіз героя - «милість за ласку, зло за зло» - породжує тенденцію до дії: вербальної і фізичної. Дія, як відомо, не $\epsilon$ 
компонентом емоції. Вона становить спільну функцію емоційного переживання й когнітивної оцінки ситуації [37, с. 488-492].

Гнів підштовхує Вате на вербальну агресію й водночас дозволяє його співрозмовникові вільно виразити свій емоційний стан

"ich wil dar gerne varn.

ob mich's künic erlieze, sô wolde ich niht bewarn,

i'ne wolde haben arebeit da ich schoenen frouwe sæhe,

daz mir und mînem künne etlîchiu fréudé von in geschæhe." [33, c. 53].

Із наведеного прикладу видно, що співрозмовник переживає почуття радості, його самооцінка підвищується, упевненість зміцнюється. Крім того, співрозмовник продемонстрував Вате свою гнучкість, рішучість, уміння усвідомлювати межі власних можливостей, диференціювати цінності на «свої» й «чужі».

Когнітивна оцінка ситуації призводить Вате до зниження продуктивності мислення: Він відступає перед «інноваційною пропозицією» другого співрозмовника - висватати дочку Гагена без бою, спокусивши їі дешевизною шовкових тканин, самоцвітів, золотих прикрас. Така тактика, безперечно, свідчить про знання жіночої психології та логіки.

Вате обурюється, наполягає на тому, що він лицар, а не купець

"ich kann niht koufes phlegen:

mîn habe ist vil selden müezic her gelegen.

ich teilde s'ie mit helden, daz ist noch mîn gedinge." [33, с. 54].

Слушно припустити, що думки й дії радісної людини якісно відрізняються від думок і дій імпульсивної розгніваної людини.

Той факт, що король від імені християнського бога благословляє сватів, підтверджує семантичний зв'язок між емоцією і релігією. Тут благословення аналогічне емоції страху, причиною якого є, з одного боку, невпевненість Гетеля в майбутній справі, 3 другого потенційна загроза життю сотням людей. Боязнь неталану й психологічних утрат можуть перевернути душевний стан кожної людини в тому числі й короля, викликати ті чи ті психічні захворювання [11, с. 305$]$.

Експериментально доведено, що соціальний статус визначає парадигму вираження емоцій. Зокрема люди з високим статусом переживають гнів «у відповідь на несхвальні результати, в той час як люди з низьким статусом більш схильні до переживань суму й провини; у випадку ж схвальних результатів люди з високим 
статусом більш схильні до переживань гордості, в той час як люди 3 низьким статусом більш схильні до переживань вдячності» [5, с. 124].

Екстраполюючи цю ідею на германську феодальну еліту XIII ст., констатуємо, що висунута гіпотеза підтверджується частково.

Наприклад, ірландський король Зігебант, як уже було показано на початку цього параграфу, переживає сум і горе через втрату малолітнього сина Гагена, а його норвезька дружина, королева Ута, залишається байдужою. Звідси виходить, що емоційна поведінка королівського подружжя залежить не від статусу, а від етносу, географії, виховання й культури вираження емоцій. Однак Гаген, будучи «депортованим» грифом на безлюдний острів, переживає інші почуття й емоції. Йдеться про страх, голод, симпатію, вдячність, гнів, лють і дружбу.

Позитивні переживання дитини - симпатія, вдячність, дружба пов'язані з принцесами, яких викрав свого часу гриф і зберіг Господь; негативні - страх, голод, гнів и лють - дотичні до афекту, стресу, невідомості (страх), браку певних речовин у тканинах зростаючого організму, втрати життєвої й психічної енергії (голод), грифа і його сімейства, графа сальмейського і його воїнів-моряків (гнів, лють).

Кількісна асиметричність позитивних (3 позиції) і негативних (4 позиції) емоцій вказує на рівень адаптації королевича в соціальній (жіночій) групі; паралель між хижаком і статусною людиною свідчить про природні інстинкти земних істот.

Королевич виявляє надмірну агресивність під час критичної ситуації, ніж його подруги або граф сальмейський. Тому з певним застереженням можна стверджувати, що емоції, емоційний досвід пропорційні віковим і гендерним особливостям, соціальному статусу й етнічності.

Співідношення соціального статусу й емоцій представлено в таблиці 1.

Як видно 3 даних таблиці 1, переживання королів і королев пов'язані з п'ятьма групами емоцій: 1) невизначеними (ірландський король Гера, (н)орманський король Гартмуот і зеландська анонімна королева, сестра Гервіга), 2) позитивними (ірландська королева Ута, індійська королева Гільда, ірландська королева Гільда, (н)ормандська королева Ортруна, ірландська королева Кудруна, зеландський король Гервіг), 3) негативними (ірландський король Зігебант, (н)ормандський король Людвіг, ірландський король Ортвін), 4) нейтральними й позитивними (норвезька 
королева Ута), 5) негативними й позитивними (ірландський король Гаген, (н)ормандська королева Герлінда).

Таблиця 1

Динаміка емоцій та соціального статусу

\begin{tabular}{|c|c|c|c|}
\hline Країна & $\begin{array}{l}\text { Соціальный } \\
\text { статус }\end{array}$ & $\begin{array}{c}\text { Власне } \\
\text { ім'я }\end{array}$ & Емоції \\
\hline Ірландія & король & Гера & не проявлені \\
\hline Ірландія & королева & $\mathrm{У}_{\text {та }}$ & любов до сина \\
\hline Ірландія & король & Зігебант & сум, горе \\
\hline Норвегія & королева & Ута & $\begin{array}{c}\text { байдужість, } \\
\text { любов до сина }\end{array}$ \\
\hline Ірландія & король & Гаген & $\begin{array}{c}\text { гнів, лють, любов до } \\
\text { дочки }\end{array}$ \\
\hline Індія & королева & Гільда & любов до чоловіка \\
\hline Ірландія & королева & Гільда & $\begin{array}{c}\text { любов до } \\
\text { батька/чоловіка }\end{array}$ \\
\hline Данія & король & Гетель & пристрасть, агресія \\
\hline (Н)ормандія & король & Людвіг & агресія \\
\hline (Н)ормандія & королева & Герлінда & $\begin{array}{c}\text { злість, гнів, } \\
\text { любов до сина }\end{array}$ \\
\hline Ірландія & король & Ортвін & $\begin{array}{c}\text { сумнів, } \\
\text { невпевненість у собі }\end{array}$ \\
\hline (Н)ормандія & королева & Ортруна & покора \\
\hline Ірландія & королева & Кудруна & $\begin{array}{c}\text { вірність чоловікові, } \\
\text { миролюбність }\end{array}$ \\
\hline Зеландія & король & Гервіг & сміливість \\
\hline (H)ормандія & король & Гартмуот & не проявлені \\
\hline Зеландія & королева & $\begin{array}{c}\text { Анонім, } \\
\text { сестра } \\
\text { Гервіга }\end{array}$ & не проявлені \\
\hline
\end{tabular}

Домінують позитивні емоції, а саме: любов, покора, вірність, миролюбність, сміливість. Любов відрізняється від ілюстрованих позитивних емоцій не тільки переживанням, але й ставленням. Можна виділити такі різновиди любові, як-от: материнська, романтична, дочірня (до батька), загальна (до всіх людей і світу). В цьому контексті любов $\epsilon$ складним і неоднозначним психічним та психологічним явищем. 


\section{2. Германські лицарі}

Прототипом германських лицарів були воїни-герої. Титул лицаря в XIII ст. міг носити кожний германський повнолітній юнак, якому виповнилось 21 рік.

Посвята в лицарі здійснювалась найчастіше в релігійні свята: на Різдво, Паску, Вознесіння, П'ятидесятницю [1]. Отже, лицарству характерні сакральність, надприродність, таємничість [22].

Претендентові вручали зброю, підв'язували золоті остроги, одягали кольчугу й каску.

Доречно зауважити, що перед одяганням кольчуги й каски юнак приймав ванну. Цей ритуал глибоко символічний. 3 одного боку, він сприяє очищенню від гріхів, з другого - змиває сліди минулого (старого) життя й водночас породжує теперішнє (нове) буття [31, с. 43-44, 253-254].

«Новобранець» зстрибував на коня, не торкаючись стремена, галопував, улучаючи списом в манекени на стовбах. «Лицарський удар» зафіксують з часом у Кодексі лицаря.

Головні риси лицаря - честь, вірність, відвага, вміння їздити верхи на коні, майстерне володіння холодною зброєю (мечем, списом) і щитом, сміливість, щедрість у подаяннях, великодушність, захист слабих і сиріт, а також догматів християнської церкви орієнтовані на ідеал. Сюди додаємо й любов до музики, поезії, дами «серця», а також самовдосконалення й самовиховання.

Можна виокремити умовно декілька категорій германських лицарів: вельможні - прості; родичі короля - друзі короля; які відзначилися в боях - які брали участь у боях; боязкі - безстрашні; найкращі; воїни - купці - співаки; яких еліта упізнавала - яких не упізнавала; здорові - поранені - каліки; лікарі; пристрасні гравці спостерігачі; літні - молоді; привабливі - непривабливі; темношкірі - світлошкірі; красномовні - мовчазні; закохані - які шукають свій ідеал; кохані - знехтувані; вигнані - панівні; багаті - бідні; «свої» «чужі»; живі - конаючі - мертві; поховані - кинуті на поталу тваринам (воронам, крукам, вовкам); християни - язичники; хрещені - нехрещені; христолюбиві - злісні.

Кожна з указаних категорій лицарів, крім мертвих, похованих, кинутих на поталу тваринам, перебуває в певному емоційному стані, що корелює із ситуацією й обставинами.

Наприклад, вельможні лицарі, будучи дуже сердитими, навіювали страх ворогам, радість і тугу дівам; прості, отримавши платню за 
службу, були задоволені життям; родичі короля, побачивши спалені й розграбовані ворогом землі, проливали сльози; друзі короля, передчуваючи поживу на полі бою, раділи й веселилися, наближаючись до брами фортеці противника, хвилювалися й тривожилися; лицарі, які відзначились у боях, сподівалися на прихильність коханої, гідне частування, щастя й чудо, укладання миру; лицарі, які брали участь у боях, старались таємно збільшити свій капітал, зрозуміти чужий біль, надати допомогу нужденним, урятувати їх від усіляких негараздів і мук тощо.

Слід зазначити, що зображені ситуації відрізняються одна від одної. Є ситуації небезпечні для життя й здоров'я людини та ситуації, що сприяють зміні статусу людини.

Критеріями розмежування ситуацій $є$ а) оцінка [35, с. 209], б) емоційне переживання й емоційний стан лицарів (афект), в) активатори емоцій, д) реактивність емоцій, е) фізичні дії, ж) конфліктність комунікативного характеру - між мовцем і слухачем [38, с. 190].

Особливо впадають у вічі жорстока помста й гіпертрофована злість лицарів, які навіюють ворогам смуток, трепет, страх. Зі страху ворог божеволів, кидався навтіки, замислювався про причини битви - кохання до Кудруни. Отже, кохання є мірою інтенсивності прояву емоцій лицаря. Більш докладно проблему кохання викладемо в параграфі 3.

Загалом, лицарі асоціюються 3 кількома семантичними підгрупами людей: 1) «універсальні» (воїни - купці - співаки), 2) «ушкодженні» (здорові - поранені - каліки), 3) «унікальні» (найкращі; лікарі), 4) «духовні» (християни - язичники; хрещені нехрещені; христолюбиві - злісні), 5) «втрачені» (поховані - кинуті на поталу тваринам (воронам, крукам, вовкам)), 6) «звичайні» (вельможні - прості; родичі короля - друзі короля; які відзначилися в боях - які брали участь у боях; боязкі - безстрашні; яких еліта упізнавала - яких не упізнавала; пристрасні гравці - спостерігачі; літні - молоді; привабливі - непривабливі; красномовні - мовчазні; закохані - які шукають свій ідеал; кохані - знехтувані; вигнані панівні; багаті - бідні; «свої» - «чужі»); 7) «інші» (живі - конаючі мертві; темношкірі - світлошкірі).

«Універсальні» лицарі мають знання і досвід, яких немає у інших «колег» у тому числі військова справа, економіка, правознавство та мистецтво. «Ушкоджені» лицарі втілюють не стільки знання у 
військовій галузі, скільки наслідки цих знань. «Унікальні» лицарі не мають собі рівних у суспільстві, їх знання і вміння тотожні Ідеалу. «Духовні» лицарі були освіченими в питаннях релігії, давали обітницю довічного служіння церкві, здійснювали христові походи, шукали християнські святині, боролися з язичниками. «Втрачені» лицарі фізично не існують. «Звичайні» лицарі нічим особливим не виділяються, їх знання і вміння очікувані вищим товариством. «Інші» лицарі $\epsilon$ своєрідним тлом для зарахування до певної семантичної групи людей.

Вихідним пунктом вияву емоцій запропонованих вище груп лицарів уважаємо їх фонові знання.

\section{3. Об'єктивація емоційного досвіду}

\section{1. Дружба. Любов}

Лінгвістичні дослідження емоцій показують, що дружба й любов $\epsilon$ моральними категоріями, основою гуманітарних (ідеальних) відносин [10].

Любов у німецьмовних поетичних творах очолює список емоцій, відображає симпатію й сильну прихильність до партнера, змінює його в кращу сторону [26, с. 168-173].

Доведено, що любові передує дружба, що її семантичне наповнення соціалізоване, окультурене, національно забарвлене на історичному тлі [28, с. 92].

В поемі «Кудруна» семантика дружби розмаїта: від мирного співіснування сусідніх королівств

Dô der künic mit kusse versuonde sînen zorn,

dô muoste man in gelden swaz sie heten verlorn.

daz was ir frume vil grôziu und was ouch Hagenen êre.

sît wúrden sie vînde mit den Islande nimmer mêre [33, с. 35] до прихильності до «чужинця», знайомого одному з рідних siu was gespil froun Hilden: sît wart ir ein rîchez lant ze lône, від союзу лицарів

"ensamet solden wesen

gerne guote friunde; sô möhten sie genesen

vor ir starken vînden immer deste baz." до миролюбності й духовної близькості er vieng in bî der hende und tet vil güetlîchen daz, від звичаїв ірландського двору

Nâch site in Irlande vil dicke man began

maniger hande freude; dâ von Wate gewan 
dan künic z'einem friunde до стану водної стихії diu wazzer müeden $\underline{h e l d e}$ ze stade siu dô giengen. // an den friunt selden froun Hilden sie dô herberge viengen, від етикету sie sach vil fremeder diete; $\underline{\text { da von was ir }}$ nâch ir friunden ande до неформального спілкування Daz edel ingesinde wart gegrüezet über al. // bî dem Hagenen kinde sâzen sie zetal, від лагідного звертання "Wate, lieber freunt, nere den vater mîn // (swie du mir gebiurest, sô will ich immer sîn) до розставання Hetelen hôchgemüete versagete im sîn kint. // friuntlîcher dienste schieden sie sich sint, від любові nu sult ir sehen ditze, daz mir mîn friedel sande до ступеня близькості й підпорядкування всіх лицарів своєму сюзерену пâch iwern besten friunden, das sie her ze hove kommen alle.

Виникнення аналізованого феномену детерміновано рівністю походження, статусу, виховання, віросповідання.

Друзів обдаровують і нагороджують цінними подарунками. В деяких випадках, наприклад, порятунок королевича, нагородою слугує не тільки відшкодування збитків, але й їжа, одяг, двотижневе проживання в замку, а також золото. Це означає, що дружба має складну ієрархічну структуру, епізодично мотивується i диференціюється. Остання обставина психологічно дуже важлива. Якщо нові друзі переконуються без усякого натиску з боку в безмежній щедрості короля, то вони, напевно, зрозуміють користь такої дружби й будуть ії обов’язково підтримувати.

Щодо теорії любові, то психоаналітики передбачають ії появу через самотність і ізоляцію людей. Виділяють декілька типів любові: братську (до всіх людей), материнську (до своїх дітей), еротичну (до партнера), до себе, до Бога [36, с. 77-98]. На жаль, ця класифікація не може бути обгрунтована науковими даними.

Емпіричне вивчення любові, що грунтується на фактовому аналізі, структурує це почуття на емоційну підтримку коханого/-ї та толерантність до його/ії вад і вимог [41]. Г. Брєслав твердить, що «возлюбленные могут существенно влиять на изменение личности партнёра» [4, с. 88]. На думку дослідника, це залежить від якості акту взаємодії: «приємні акти» зумовлюють появу й підсилення позитивного почуття, «неприємні», навпаки, гальмують його [там само, с. 89].

Уявлення про любов комплексне, включає різноманітні компоненти в тому числі соціальні й психологічні nâch sînes vater tôde volgte im beide freude und michel wünne, психологічні й моральні jâ wuohs er dâ mit sorgen in sînen jungen tagen, біологічні 
й психологічні si ervánt diu wâren bilde. do enphiengen sie den jungen helt vil schône. // Mit wéinénden ougen sie kuste in an den munt, культурні, психологічні й психічні Der künic trat dar nâher, sîn freude diu was grôz. // von sînes herzen liebe ûz sînen ougen vlôz, психологічні й культурні

Diu ellenden fremeden froun Uoten wurden kunt.

sie gap in maniger hande grã únde bunt,

phelle ob liehten vederen, daz wol gezam ir lîbe.

sich ringel' ir gemüete von des künic Sigedandes wîbe,

\section{психологічні й раціональні}

Hagene sîne frouwen niht unberuochet liez.

baden ze allen zîten er s' vlîziclîchen hiez.

den minneclîchen meiden den diende er vil lîse.

man gab in rîchiu kleider; er was in sînen jungen jâren wîse,

соціальні, політичні й психологічні

"nu râtet ir mir daz,

daz ich ein künic heize. ez zimt mir deste baz,

ob ich von herzen minne diu bî mir trage krône.

ich erwinde nimmer unz ich ir ir arebeit gelône.",

фізичні й духовні

Sun der Sigebandes den bûhurt selbe reit.

daz sach sîn triutinne; jâ was ez ir niht leit.

ob siu im iht gedienet het in fremeden landen,

des lônde er ir gerne; er was ein mærer helt ze sînen handen,

когнітивні й духовні

Inner zwelf jâren diu hêrlîche meit

wart unmâzen schœene. verre ez wart geseit.

edele fürsten rîche die begunden sinnen,

wie sie wolden werden nâch des wilden Hagenen tohter minnen,

психічні й філософські

Noch beléip ez ungeworben von guoten recken niht.

hât ir einer übermuot, alsô man des gibt,

dâ bî man vindet einen, der dunket sich sam hére.

von ir hôhen minne huop sich sîner sorgen deste mêre,

естетичні й біологічні

Sîn liet erklang im schône, ie hôher und ie baz.

Hagene ez selbe hôrte; bî sînem wîbe er saz.

духовні й психологічні

"so enbiutet er dir daz, 
daz dich sîn herze minnet ân' aller slahte haz.

nu lâz in geniezen, frouwe, dîner güete.

er hât durch dich eine genómen von állen frouwen sîn gemüete.",

теологічні й психологічні

"got müeze im lônen, daz er mir wæge sî.

kome er mir ze mâze, ich wolde im ligen bî тощо.

Трапляється маніакальна любов, яку переживає (н)орманський королевич Гартмуот (букв. «твердий духом») до красуні Кудруни (букв. «божественна таємниця»). Він готовий іти в небезпечний похід, домагатись любові зброєю. В контексті етимології імен «твердий дух» тягнеться до «божественної таємниці», мріє ії не лише підкорити й завоювати, але й злитися 3 нею тілесно. Найімовірніше намагаються поєднати ідеальне й матеріальне, духовне й земне.

Зауважимо, що маніакальна любов збігається 3 ідеальним образом або еталоном жіночої вроди. Цей образ формується на основі естетичної інформації про зовнішність королівни, що дистанційно вливає на чуттєвого й вразливого королевича.

Врода коханої не підвладна фізичному часу, не залежить від його руху та якості, тобто вона вічна, стала, безкінечна. Вічна краса «зустрічається в природі та у витворах мистецтва» [14, с. 13]. Звідси випливає, що вродлива шляхетна жінка має особливу цінність у процесі біологічного добору, для формування соціальних стандартів і норм та загальнокультурного розвитку.

У річищі етимології краса постає як специфічний механізм зміни й трансформації навколишнього світу [7, с. 27-28; 40, с. 762].

Метафоричними посередниками між жіночою красою (тілом) і чоловічою «маніакальністю» (пристрасть) $\epsilon$ кров воїнів, що загинули в нерівному бою, мародерство, руїни замку, спалене місто, безліч прегарних полонянок (60 шляхетних дівчат).

В описі динаміки міжособистісних стосунків «маніяка» й бранки виділяємо умовно чотири етапи: 1) шанобливо-ввічливий; 2) грубосуворий; 3) агресивно-жорстокий та 4) гуманний.

На першому етапі - шанобливо-ввічливому - королевич рятує Кудруну від смерті, захищає від свого немилосердного батька, радить своїй літній матері зустріти «гостю» радісно, лагідно, ніжно, обіцяє королівні корону, наказує всім у замку служити ӥй вірно.

На другому етапі - грубо-суворому - розгніваний Кудруною королевич віддає дівчину на «перевиховання» своїй злій, жорстокій, 
лютій матері та йде в похід. Спочатку королева терпляче навчала принцесу, без приниження й образ. Оскільки наука не пішла на добро, вона почала погрожувати красуні «чорною роботою», розлучила з іншими дівчатами, посадила за прядку.

На третьому етапі - агресивно-жорстокому - королева позбавила Кудруну їі почту, шляхетних занять і утіх, погано годувала, мстилась за чесноти, звеліла топити піч, мести королівські покої тричі на день. Тиранія й насилля тривали дев'ять років. Потім бранка впродовж шести років прала білизну королеви, сукні всього почту, одяг королівських охоронців на березі моря, ходила босоніж узимку, мешкала зі служницями на задвірках.

На четвертому етапі - гуманному - Гартмуот заступається за скривджену королівським дружинником Кудруну. Він готовий віддати своє життя за неї, доводячи своє кохання. Гуманність «маніяка» дає змогу зробити висновок про глибину його естетичних почуттів та душевний стан. Естетичні почуття позитивно впливають на лицаря, розкривають кращі сторони його характеру, зміцнюють віру в правоту вибору «дами серця», «перезавантажують» душевний стан із грубої (фізичної) енергії володіння гарним тілом - на більш тонку - духовну, орієнтовану на внутрішній психічний світ (романтична любов).

Маніакальна любов триває понад 15 років, тобто до тих пір, поки Кудруну не звільнили з полону її родичі.

\section{2. Об'єктивація емоцій}

Спостереження над емпіричним матеріалом показує, що емоції визначають модель і варіативність поведінки людини, її характер, ставлення до навколишнього світу, других людей, релігії. Крім того, емоції забезпечують соціальний зв'язок а) між дитиною й дорослим (до семи років спадкоємців престолу виховують жінки, потім чоловіки), б) між дорослими людьми (сигналізують про потреби в їжі, воді, теплі, догляду, захисту тощо).

Уже з перших строф поеми знайомимось із назвами емоцій (êre «честь», nôt «горе») (тут і далі переклад на українську мову наш.- Н.Р.), емоційними переживаннями (prîsen «хвалити»), емоційним станом (betrâgen «злити, засмучувати», was wê «мучити, шматувати»), його динамікою (begungen îlen «захапатися») й статикою (bedecket man die strâze vant vil wol in vierdehalber mîle «народ заповнив усе вулиці в окрузе на три з половиною милі»), 
оцінкою (getiwert wurde «поліпшено», freude und michel wünne «радість і блаженство»), реакцією (beháget' im wól «йому б дуже сподобалось», fuoren gerne «поїхали із задоволенням»), змістом емоцій (mit grôzer arebeit «великі муки»), їх безпосереднім вираженням (ah! wie hohes muotes der vogt von Irlande was!), функціями (er rihte swen er solde und rach der armen anden. // er was

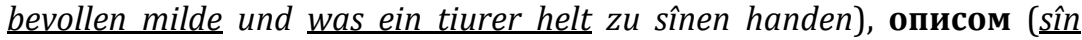
phlâgen wîse frouwen und vil schœne meide: // sîn vater und sîn muoter sâhn an im ir liehten ougen weide), модальністю (Si enphiengen'n güetlîchen: dicke bî der stunt // wart er von den frouwen geküsset an den munt) (позитивне ставлення дівчат до пропозиції Гагена повеселитись на свіжому повітрі, а не в печері: емоція радості), (daz schif begunde krachen. die bî in fuoren nâhen, // sie vorhten wildiu merkint, dô sie die frouwen an dem stade sâhen) (негативне ставлення моряків до зовнішнього вигляду дівчат - їх убрання було із зеленого моху та до казкових водних істот - русалок: емоція страху).

Емоційна сфера чоловіків і жінок асиметрична

Der wirt weinde sêre, sîn brüst diu wart im naz.

diu edele küniginne mit zühten sprach dô daz daz er die klage lieze. "læg' ál daz liut tôt,

ez müese sich verenden, als got von himele gebôt.".

Чоловік заявляє про себе як чуттєва, емоційна, милосердна, пасивна й слабка особистість, тобто він фемінізований, жінка, навпаки, виявляє себе як раціональна, стримана, прагматична, активна й сильна особистість, тобто вона маскулізована.

Таку контрастність у поведінці можна пояснити соціокультурними чинниками, різними системами освіти й виховання, характером, темпераментом, емоційною збудливістю, чуттєвістю, психічним станом тощо [16, с. $14-24,40,100]$. Сюди відносимо й вияв емоцій старшим і молодшим поколіннями. Старше покоління реагує на життєві ситуації в рамках віросповідання, звичаїв і культури

Ez was noch unerstorben, wan ez got gebôt;

iedoch het ez besunder dar umbe gróze nôt, wan ez der alde grîfe den sînen jungen truoc.

dô ez die vor in hêten, dô het ez arebeit genиос, молодше спочатку оцінює життєву ситуацію, потом на неї реагує

Der herre gíe bálde da er die maget vant

in trûriclîcher wîse. dô was der megede hant

an ir vater kinne. siu bat in vil sêre. 
siu sprach: "liebez veterlîn, heiz in singen hie ze hove mêre.".

Особливе значення для молодшого покоління мають честь і вірність, яких дотримуються навіть при самих жорстоких обставинах Ir wizzet wol, her Hartmuot, swie iuwer wille stât,

daz man mich bevestent einem künige hât

mit vil stæeten eiden z'eim' êlîchen wîbe.

ez'n sî daz er sterbe, ich gelíge nímmér bî recken lîbe.".

У вишуканій відповіді королівни виявляємо зарозумілість і зверхність над ворогом-мучителем. Її презирство має, з одного боку, генеалогічне коріння

Dô sprach diu Hilden tohter: "wan lât ir mich ân' nôt?

ê ich Hartmuoten næme, ich wolde ê wesen tôt.

im enwære ez von dem vater geslaht daz er mich solde minnen,

den lîp wil ich verliesen, ê ich in ze fríundé gewinne.", з другого соціально-культурне Siu sprach: "wer wær' diu frouwe, der versmâhte daz, // der ein helt sô diende, daz siu dem trüege haz?, з третього - гуманістичне

"Frouwe, dir riet selden disiu schœene meit",

sô sprach aber Kûtrûn, "dehein herzen leit.

gedenke, liebin muoter, waz ich des hiete schulde,

swen slüegen mîne mâge. lâz die armen haben dîne

hulde.".

Мовленнєвими маркерами ілюстрованих емоцій є словосполучення а) вільні weinde sêre "гірко плакала», z'eim' êlîchen wîbe «його законною дружиною», б) стійкі die klage lieze «не голосити», herzen leit «страждати», waz schulde «бути винуватим», речення а) прості sîn brüst diu wart im naz «його груди були мокрими», iedoch het ez besunder dar umbe gróze nôt «тому він побивався», dô het ez arebeit genиос "мук було багато», dô was der megede hant an ir vater kinne «дівоча рука лежала на підборідді іiі батька», siu bat in vil sêre «вона його благала», ich gelíge nímmér bî recken lîbe «я ніколи не ляжу в ліжко з другими лицарями»; wan lât ir mich ân' nôt? «якщо ви меня примусите силою?», б) складні den lîp wil ich verliesen, ê ich in ze fríundé gewinne «я віддам життя, але не стану йому дружиною», wer wær' diu frouwe, der versmâhte daz, // der ein helt sô diende, daz siu dem trüege haz? "хто та жінка, що цим нехтує, // їй служить герой, а вона його ненавидить?», кліше liebez veterlîn «любий батенько», liebin muoter «люба матінко», емотивна лексика minnen «любити». 
Семантика стійких словосполучень або фразеологічних одиниць відображає емоцію горя die klage lieze «не голосити», herzen leit «страждати», емоцію провини waz schulde «бути винуватим», семантика емотивної лексики вказує на емоцію любові.

На емоційний досвід середньовічної людини, як уже неодноразово зазначалось, впливає його віросповідання: Язичник веселий і безтурботний, християнин - сумний і відповідальний.

Весела й безтурботна людина не реагує на «духовних ворогів», сумна й відповідальна диференціює їх учинки: «пряма жертва» переживає жах (дитина, спадкоємець престолу) Ez begunde lûte erschrîen, ez waz sêre erschraht, «непряма» а) одинична переживає горе (батько-король) daz muoste dô beweinen ûzer Îrlande der herre, б) множинна співчуває втраті (друзі нещасного батька-короля) Sigebandes friunde frieschen dise nôt; // sie klagten harte sêre des kindelînes tôt, тужить (рідні) des was in unmuote der künic und ouch sîn wîp, жалкує (добрі люди) sie klagten algemeine des kindes wætlîchen lîp.

3 наведених прикладів видно, що емоції переживають особисто й колективно. «Особисті» емоції містять ознаки інтенсивності й драматизму (жах, горе), «колективні» орієнтовані більше на звичаї й моральні норми (співчуття, скорбота, жаль).

Про істинний ступінь інтенсивності емоцій дізнаємося 3 висловлювань. Зокрема Гаген гнівно кричить на графа сальмейського через полон ich will niht gisel wesen. // des enmuote niemen, der wéllé genesen. У бурхливій реакції юнака простежуємо не тільки протистояння волі старших, але й самостійність підлітка, його ставлення до свободи, лицарської долі, бажань графа. Тут немає прагнення викликати певну емоцію в слухачів.

Мовленнєвими маркерами вираження емоції гніву слугує модальне дієслово will «хотіти» із запереченням niht «не» та іменник mиote «сміливість» із запереченням еп«не». Без слів автора Der recke sprach in zorne «Герой сказав гнівно» виявити модальність емоції дуже складно, оскільки пунктуація - двокрапка, крапка, кома відображає певне підвищення тону (двокрапка, кома) або сильне зниження (крапка), а не стан афекту (знак оклику) [6, с. 20-21].

Необхідно звернути увагу й на джерело формування емоції гніву королевича. Воно невід'ємне від клімату й географії, особистого життя, умов проживання, довколишніх обставин, фізичного й психічного розвитку дитини. Треба думати, що семирічний хлопчик 
без опіки старших рано стає дорослим та швидко дозріває розумово. Він виявляє свої воїнські здібності та свій героїзм

In sînen siten tumben grimme er was genuoc.

dem grîfen einen vetechen er von der ahsel sluoc,

und verhíew in aneme beine starke unde sêre,

daz er getragen mohte von der stete sînen lîp niht mêre.

Емоцію гніву описано лексикою а) емотивною grimme «гнів», б) оцінною gепиос «досить», вільними словосполученнями із соматичним значенням ahsel sluoc «ударив по плечу крила», verhíew in aneme beine «посік йому одну ногу», lîp niht mêre «мертвий», парними інтенсифікаторами, що підсилюють висловлювання starke unde sêre «глубоку й несумісну з життям».

Семантика емотивної лексики (grimme) апелює до негативного емоційного стану.

Розвиток емоції гніву з роками переростає в рису характеру королевича як особистості der wilde Hagene «дикий Гаген». Цікаво, що «дикий Гаген» готовий вести переговори про мир між ворогуючими правителями Ірландії і Гарадеї

Dô sprach der junge Hagene: "unschúldic ich des bin

daz sie iu getâten, nu bríngét mich z'in;

so getróuwe ich wol versüenen ir haz und iuwer strîten.

lât mich genendiclîche zuo den mînen kúndén erbîten.".

Мовленнєві маркери примирення охоплюють словосполучення з модальним дієсловом і інфінітивом другого дієслова wol versüenen «хочу угамувати», емотивну лексику haz «злість, ненависть», strîten «чвари», genendiclîche «негайно», семантика якої номінує а) емоцію ненависті $h a z$, б) об’єкти (носії негативного емоційного стану) strîten, в) якість і оцінку genendiclîche.

Наведемо приклад інтенсивності емоційного патерна гнів-горе старшої королівни при зустрічі з незнайомцем на безлюдному острові

Dô sprach diu éltíste: "wie getárst du zuo uns gân,

sît wir von gote von himele dise hérberge hân?

nu suoche dîn genôze in dem wilden sê.

wir lîden dóch árebeit; uns ist hie grœezlîchen wê.".

Мовленнєвими маркерами інтенсивності емоційного патерна гнів-горе $\epsilon$ риторичні питання wie getárst $d u$ zиo uns gân «як ти потрапив до нас?», sît wir von gote von himele dise hérberge hân? «нам Бог тут дарував притулок?», прості поширені речення а) імперативне пu suoche dîn genôze in dem wilden sê «шукай собі 
подібних у вирі буйних вод!», б) розповідне uns ist hie grœzlîchen wê «у нас тут доволі страждань», емотивна лексика lîden «страждати», dóch «адже», árebeit «мука».

Семантика аналізованих риторичних питань, простих поширених речень - імперативного й розповідного - реалізує інтенсивність емоції гніву, семантика емотивної лексики маніфестує інтенсивність емоції горя, вказуючи при цьому на психічний процес lîden, емоційно-оцінне ставлення до ізольованого життя і водночас до нового полоненого тированной жизни dóch, емоційний стан árebeit.

Конвергенція емотивної лексики відображає найвищий ступінь емоційного напруження висловлювання.

Викликає інтерес відповідь малолітнього королевича, який говорить палко, просто, щиро

Dô sprach daz edele kindel: "lât mich iu wesen bî.,

ob ir daz welt gelouben, daz ich ein kristen sî.

mich truoc der wilden grifen einer zuo dem steine,

ich wære bî iu gerne; jâ mag ich hie niht belîben eine.".

У наведеному прикладі хлопчик дуже переживає не стільки через примусову розлуку зі своїми батьками, няньками, виховательками, скільки через самотність. Він, очевидно, боїться відмови, тому формулює свої думки ввічливо, дипломатично, в рамках придворного етикету, намагається задовольнити співрозмовницю, здогадуючись про те, на яку відповідь вона очікує від нього.

До мовленнєвих маркерів імпліцитної емоції страху належить емоційний синтаксис: імперативне речення 3 модальним дієсловом зі значенням «дозволяти» і інфінітивом другого дієслова lât mich iu wesen bî, просте поширене розповідне речення в кон'юнктиві 3 емотивним прислівником ich wære bî iu gerne, негативне просте поширене розповідне речення 3 емотивною часткою, модальним дієсловом зі значенням «бажання» i інфінітивом другого дієслова jâ mag ich hie niht belîben eine.

Семантика цих речень еквівалентна проханню, квазіреальній довірі, емотивній оцінці з лінійкою «добре - погано».

В емоційній поведінці правителів проявляються типологічні особливості вищої нервової діяльності, що змінюються під впливом зовнішніх діянь, наприклад, емоцію радості король виражає невербально 
Der künic trat dar nâher, sîn freude diu was grôz. von sînes herzen liebe ûz sînen ougen vlôz

ime der vil heizen trâhene dâ genuoc.

dem kinde er holden willen von schulden fríuntlîchen truoc.

Маркери аналізованої емоції - вільні словосполучення зі значенням проксемики trat dar nâher «наблизився», емотивна лексика freude, diu «радість», liebe «любов», holden «любити», schulden «провина», fríuntlîchen «душевний», соматизми herzen «серце», ougen «очі», оціночна лексика gепиос «достатньо», волюнтатив willen «хотіти».

Семантика емотивної лексики зв'язана з назвою емоції freude, diu, liebe, schulden та психічним процесом holden.

\section{Висновки}

Підсумовуючи, зазначимо, що палітра емоцій середньовічної людини різноманітна: від міфопоетичної до поетичної. Міфопоетичні емоції успадковані від дохристиянського або язичницького часу, поетичні емоції забарвлені християнськими ідеями. З'являється поняття гріха й розплати за кривду, заподіяну пілігримам під час паломництва, усвідомлення провини, що очищає грішну душу через пожертву, будівництво храму, молитву тощо. Тобто емоція провини стає дієвим і практичним засобом. 3 християнською ідеологією безпосередньо пов'язане появлення птаха-Янгола, що приплив по морських хвилях і відкрив королівні Кудруні її недалеке майбутнє. Він говорить людською мовою, проголошує себе вісником Божим, посланником Христа. Птах-Янгол оцінює емоційно психічний стан героїні, називаючи їі «нещасною». Він - носій позитивних (утіха, любов, мораль) і негативних (гнів) емоцій, втілення чудес, що творить Господь на Землі. Після зникнення птаха-Янгола до королівни приходить усвідомлення всепрощення, миру для всіх переможців і переможених, маврів і християн. При цьому емоцію ненависті необхідно трансформувати в емоцію любові. Механізмом трансформації емоції ненависті вважають пораду або поради вельможних/шляхетних людей. Ці поради завжди добрі й справедливі, настроюють адресата на довіру, знімають у нього емоційне напруження, сприяють емоційному перетворенню. Іншими словами, поради правомірно розуміти як своєрідні сеанси психотерапії. Психічна сфера середньовічної людини (кардинально) змінюється, а її зовнішній вигляд залишається вічно молодим i 
прекрасним. Молодість і врода характерні лише жінці. Причина суперечності між внутрішнім і зовнішнім світом, між душею і тілом полягає у відсутності знань про людину як особистість. Домінує внутрішній світ і душа, але захоплюються вродою, красою тіла i вчинками, наприклад, солодким співом датського воїна Горанта. Цей спів зачаровує все живе: людей, тварин, птахів, комах, риб тощо, спиняє фізичний і душевний біль, стримує муки, розганяє турботи, зцілює хворих, веселить дух. Талант не лише підносить середньовічну людину до Бога, а й ототожнює ії з Ним. Таким чином, емоційний досвід германського феодального товариства XIII ст. $€$ «міксовим», включає в себе природні (язичницькі), святі, сатанинські та естетичні (християнські) емоції. Вербалізація емоцій лексикофразеологічними й синтаксичними засобами відбувається порізному в залежності від мовної та емоційної картин світу шпільмана. Виокремлено три вербальні рівні з чотирьох теоретично можливих: «нульовий», перший і другий. «Нульовий» (алекситимічний) рівень характеризується відсутністю лексичних і фразеологічних засобів об'єктивації емоцій, перший рівень визначає емоції узагальнено через предметно-емотивні слова, словосполучення, фразеологічні та синтаксичні одиниці, другий рівень конкретизує емоції певної модальності через емотивну, емотивно-оцінну, соматичну лексику, емотивно-предметні словосполучення і фразеологічні одиниці, кліше, емоційний синтаксис.

\section{Список використаних джерел:}

1. Бартелеми Д. Рыцарство: От древней Германии до Франции XII века / пер. с фр. М.Ю. Некрасова. Санкт Петербург: ЕВРАЗИЯ, 2012. 584 c.

2. Безугла Л.Р., Романченко І.О. Лінгвопрагматика дискримінації у публіцистичному дискурсі. Харків: ФОП Лисенко І.Б., 2013. 182 с.

3. Біблія або Книги Святого Письма Старого й Нового Заповіту / пер. з дєвр. й гр. професора Івана Огієнка. Київ: Українське Біблійне Товариство, 2015. 1232 с.

4. Бреслав Г.М. Композиционная теория эмоций: к пониманию моральных эмоций и любви. В: Психология. Журнал высшей школы экономики, 12, 4. 2015. С. 81-102.

5. Бреслав Г. Психология эмоций. Москва: Смысл, 2006. 544 с. 
6. Бровченко Т.А., Волошин В.Г., Петлюченко Н.В. Соотносимость информационных единиц просодии устного и письменного текста. В: Записки з романо-германської філологї̈, 32, 2008. С. 13-25.

7. Гайсина Р.М. «Глагол $\leftrightarrow$ имя»: взаимодействие и взаимообогащение. В: Учёные записки Таврического национального университета имени В.И. Вернадского. Серия "Филология. Социальные коммуникации», 25 (64), 4. Ч. 2, 2012. С. 25-31.

8. Гамзюк М.В. Емотивний компонент значення у процесі створення фразеологічних одиниць: На матеріалі німецької мови. Київ: Видавничий центр КНЛУ, 2000. 256 с.

9. Горбань Ю.А., Білик Б.І., Дячук Л.В. та ін. Історія сучасного світу: соціально-політична історія XV - XX століть. Київ: Знання, 2007. 439 c.

10. Дягілєва Ж.А. Фразеологічні засоби вербалізації концепту FREUNDSCHAFT в німецькій мові: семантичний і структурний аспекти. В: Гамзюк М.В. (відп. ред.) Німецька фразеологія в Україні (до 80-річчя з дня народження Володимира Івановича Гаврися). Київ: Видавничий центр КНЛУ, 2012. С. 148-163.

11.Изард К.Э. Психология эмоций. Санкт-Петербург: Питер, 2008. 464 c.

12. Исянгулова Г.А. Проблема происхождения, изучения и классификации междометий. В: Вестник Башкирского университета, 3, 20. 2015. С. 1064-1067. ISSN 1998-4812

13. Карасик В.И. Языковой круг: личность, концепты, дискурс. Волгоград: Перемена, 2002. 477 с.

14. Коваль I.I. Вербалізація концепту SCHÖNHEIT у лексичних та фразеологічних одиницях німецької мови: лінгвокультурологічний аспект. Автореф. дис. ... канд. філол. наук: 10.02.04 - германські мови. Херсон: Херсонський державний університет, 2018. 20 с.

15. Кордуэлл М. Психология. А-Я: Словарь справочник / пер. с англ. К.С. Ткаченко. Москва: ФАИР-ПРЕСС, 2000. 448 с.

16.Крутецкий В.А. Психология обучения и воспитания школьников. Москва: Просвещение, 1976. 303 с.

17. Максименко С.Д. Загальна психологія. Київ: Центр учбової літератури, 2018. 272 с.

18. Новикова М. Діалог із предківщиною. В: Ойкумена, 2. 1992. C. 104-107. 
19. Новикова М.А., Шама И.Н. Символика в художественном пространстве. Символика пространства. Запорожье: СП «Верже», 1996. 172 c.

20. Пименов Е.А., Пименова М.В. Антропоморфизм как один из способов концептуализации внутреннего мира человека. В: Попова З.Д., Стернин И.А., Карасик В.И. и др. Введение в когнитивную лингвистику. Севастополь: Рибэст, 2009. С. 184-212.

21. Пименова М.В. Концептосфера внутреннего мира человека. В Попова 3.Д., Стернин И.А., Карасик В.И. и др. Введение $в$ когнитивную лингвистику. Севастополь: Рибэст, 2009. С. 128-183.

22. Прилукова Е.Г. Сакральность как атрибут власти. В: Вестник Челябинского государственного университета. Философия. Социология. Культурология, 2 (217), 20.2011. С. 35-38.

23. Приходько А.И. Семантика и прагматика оценки в современном английском языке. Запорожье: Запорожский государственный университет, 2004. 321 с.

24. Пугавко Т. Половое созревание: что нужно знать родителям? URL: https://centrsna.by (дата обращения: 15.10.2021).

25. Пуришев Б. Лирическая поэзия средних веков. В: Поэзия трубадуров. Поэзия миннезингеров. Поэзия вагантов. Москва: Издательство «Художественная литература», 1974. С. 5-28.

26. Романова Н.В. Етнос. Мова. Мовлення. Херсон: ТОВ «ВКФ» «СТАР»«ЛДТ», 2018. 460 с.

27. Романова Н.В. Емоції у німецькомовних біблійних текстах Старого Заповіту. Херсон: Айлант, 2019. 284 с.

28. Синявская О.Е., Чой Ю. Лексикографическая обработка концепта ДРУГ/FRIEND. B: Науковий вісник Херсонського державного університету. Серія: Германістика та міжмовна комунікація, 1, 2019. C. $90-96$.

29. Стрельников А.И., Стрельникова Л.Л. Беседы о неизвестном. Москва: Амрита-Русь, 2005. 256 с.

30. Токарев C.A. Проблемы общественного сознания доклассовой эпохи. В: Решетов М. (отв. ред.) Охотники, собиратели, рыболовы. Ленинград: Наука, 1972. С. 236-279.

31. Тресиддер Дж. Словарь символов / пер. с англ. С. Палько. Москва: ФАИР-ПРЕСС, 2001. 448 с.

32. Шаховский В.И. Категоризация эмоций в лексикосемантической системе языка. Москва: Издательство ЛКИ, 2008. 208 с.

33. Bartsch K. (ed.). Kudrun. Leipzig: F.A. Brockhaus, 1867. 
34. Belekhova L.I. Integrated model of poetic text interpretation. B: Просяннікова Я.М. (відп. ред.). Різноаспектне досліжження поетичного мовлення. Херсон: Айлант, 2018. С. 70-79.

35. Fillmor Ch. Types of lexical information. In: Studies in syntax and semantics. Dordrecht, 1969.

36. Fromm E. The Art of Loving. New York: Harper \& Row, 1956.

37. Izard C.E. Facial expressions and the regulation of emotions. In: Journal of personality and social psychology, 58 (3). 1990. P. 487-498.

38. Miall D.S. Anticipating the Self: Toward a Personal Construct Model of Emotion. In: International Journal of Personal Construct Psychology, 2, 1989. P. 185-198.

39. Ortony A., Clore G.L. \& Foss M.A. The referential structure of the affective lexicon. In: Cognitive science, V, 11, 1987. P. 341-364.

40. Paul H. Deutsches Wörterbuch. Tübingen: Max Niemeyer Verlag, 1992.

41. Swensen C. \& Gilner F. Factor analysis of self-report statement on love. In: Journal of Individual Psychology, 20, 1964. p. 186-188.

42. Thoits P.A. Emotion norms, emotion work and social order. In: Feelings and emotions: The Amsterdam symposium. New York: Cambridge University Press, 2004. P. 359-379. 